\title{
Amyloid A Measurement
}

National Cancer Institute

\section{Source}

National Cancer Institute. Amyloid A Measurement. NCI Thesaurus. Code C125940.

The determination of the amount of amyloid A present in a sample. 